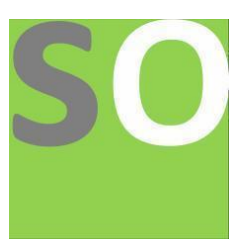

Article title: Green Synthesis of Silver Nanoparticles Using Alagaw (Premna odorata) Leaf Extract

Authors: Peter Jay Corros[1], Jeremie Germina[2], Kimberlyn Ferrer [3]

Affiliations: Capiz State University - Main Campus[1]

Orcid ids: 0000-0003-2757-7224[1]

Contact e-mail: pjcpotterboy@gmail.com

License information: This work has been published open access under Creative Commons Attribution License http://creativecommons.org/licenses/by/4.0/, which permits unrestricted use, distribution, and reproduction in any medium, provided the original work is properly cited. Conditions, terms of use and publishing policy can be found at https://www.scienceopen.com/.

Preprint statement: This article is a preprint and has not been peer-reviewed, under consideration and submitted to ScienceOpen Preprints for open peer review.

DOI: 10.14293/S2199-1006.1.SOR-.PPAEJOG.v1

Preprint first posted online: 13 May 2021

Keywords: Nanoparticles, Biosynthesis, Absorbance Spectrum 


\title{
Green Synthesis of Silver Nanoparticles Using Alagaw (Premna odorata) Leaf Extract
}

\author{
Peter Jay B. Corros, Kimberlyn A. Ferrer , Jeremie M. Germina \\ Bachelor of Secondary Education Major in Physical Science, Capiz State \\ University - Main Campus, Roxas City, Capiz, Philippines \\ pjcpotterboy@gmail.com, tropangjeremie@gmail.com, \\ ferrerkimberlyn5@gmail.com
}

\begin{abstract}
There is a worldwide interest in silver nanoparticles (AgNPs) synthesize by various chemical reactions for use in applications. Silver nanoparticles have gained significant interest due to their unique optical, antimicrobial, electrical, physical properties and their possible application. However, it is necessary to develop environmental friendly methods for their syntheses. To avoid chemically toxicity, biosynthesis of metal silver nanoparticles is proposed as a cost-effective and environmental friendly alternative. This study aimed to find out whether Alagaw plant can potentially act as a reducing agent for the biosynthesis of silver nanoparticles and whether the concentration of the leaf extract can affect the absorbance spectrum, size and shape of the synthesized silver nanoparticles. The synthesized silver nanoparticles were characterized using the UV-vis spectroscopy for its absorbance spectrum and Transmission Electron Microscope Analysis for its morphology and size. The experimental method of research was used using three treatments and replicates of the different concentrations of Alagaw leaf extract: Treatment A $(0.2 \mathrm{~g} / \mathrm{mL})$, Treatment B $(0.4 \mathrm{~g} / \mathrm{mL})$ and Treatment $\mathrm{C}(0.6 \mathrm{~g} / \mathrm{mL})$ with 10 minutes and 60 minutes interval of observation under UV-vis spectrophotometer. Based on the findings of the study, Alagaw plant can potentially act as a good reducing agent for the biosynthesis of silver nanoparticles. The results recorded from UV-vis spectrophotometer support the biosynthesis and characterization of silver nanoparticles that as the concentration of the leaf extract increases it significantly affect the wavelength peaks and absorbance peaks of the synthesized silver nanoparticles. Using the high-resolution Transmission Electron Microscopy, the size of silver nanoparticles measured $50 \mathrm{~nm}-100$ $\mathrm{nm}$ having near-spherical in shape.
\end{abstract}

Keywords: Nanoparticles, Biosynthesis, Spectroscopy, Absorbance Spectrum

\section{A. Introduction}

Silver nanoparticles have been the subject of this research due to their unique physical, chemical, and biological properties that is very beneficial to various fields including medical, food, health care, consumer, electricity, and industrial purposes. Its optical, antimicrobial, electrical and thermal properties are usually incorporated into products that range from photovoltaic to biological and chemical sensor. Silver nanoparticles' high electrical conductivity, stability, and low sintering temperature are utilized into conductive inks, pastes and filters (Gurunathan, et al., 2015). 
There are various chemical and physical methods for the synthesis of metallic nanoparticles for example, one can use reduction of solutions, photochemical reactions in reverse micelles, electrochemical reduction, heat evaporation and radiation assisted methods, among others. These methods have usually been successful in the synthesis of nanomaterial in large quantities in short period of time, as well as for specific size and shape (Kuppusamy, et al., 2015).

The problem is, most of these methods are extremely expensive and involves the use of toxic, hazardous chemicals as the stabilizers which may pose potential environmental and biological risks. This challenge gives rise to the idea in using the green synthesis method for the biosynthesis of silver nanoparticles since it is cost-effective and biocompatible alternative to chemical and physical methods. Plant-mediated synthesis or simply the green synthesis of nanoparticles is green chemistry approach that highly associates nanotechnology with plants.

Thus, this study uses Premna odorata B. which is a Philippine native plant, and is locally known as Alagaw or Argaw since its family is known to have an antimicrobial, anticancer, and antioxidant property which can potentially act as a reducing agent to synthesize metallic nanoparticles. This also leads to the question whether Alagaw leaf extract can potentially act as reducing agent for the biosynthesis of silver nanoparticles.

\section{B. Statement of the Problem}

This study aimed to find out whether Alagaw plant can potentially act as reducing agent for the biosynthesis of silver nanoparticles. Specifically, this study sought to find out the following:

1. To determine the effect of the concentration of Alagaw leaf extract on the biosynthesis of silver nanoparticles in terms of its absorbance spectrum in 10 minutes and 60 minutes interval, size, and shape.

2. To determine the absorbance spectrum of each Treatments in 10 minutes vs. 60 minutes interval.

3. To determine the absorbance spectrum of all the Treatments in 10 minutes and 60 minutes interval.

4. To determine the average wavelength peaks and average absorbance peaks of silver nanoparticles in terms of the concentration of Alagaw leaf extract in 10 minutes and 60 minutes

5. To determine the speed and stability of the reaction of the solution in terms of its average wavelength and absorbance peaks.

6. To determine the best concentration of Alagaw leaf extract on the biosynthesis of silver nanoparticles in terms of the speed and stability of reaction.

7. To determine if there is a significant difference on the effect of the concentration of Alagaw leaf extract in terms on the wavelength peaks of silver nanoparticles in 10 minutes interval, 60 minutes interval and between 10 minutes and 60 minutes interval.

8. To determine if there is a significant difference on the effect of the concentration of Alagaw leaf extract in terms on the absorbance peaks of silver nanoparticles in 10 minutes interval, 60 minutes interval and between 10 minutes and 60 minutes interval.

9. To determine the morphology and size distribution of silver nanoparticles.

\section{Significance of the Study}


The result of this study would benefit various fields including biology, chemistry, electricity, and even medicine. Also, it is beneficial to other researchers, professionals, and society.

Biology. The result of this study would give insights in the field of biology in terms of the kinds of plant that have the quality of good reducing agents.

Chemistry. This is for the chemical applications since silver nanoparticles can be utilized to enhance the efficiency and efficacy of chemical reactions. The same factors also make them of use in chemical vapor sensors and other devices.

Electricity. Silver nanoparticles are utilized in a number of conductive products, including conductive adhesives, LCD and LED screens, touch screens, and conductive slurries used in microelectronics.

Medicine. The silver nanoparticles in this study can highly benefit the field of medicine because of the application of silver nanoparticles on biomedical applications, including diagnosis, treatment, drug delivery, medical device coating, and for personal health care.

Other researchers. The result of this study would highly benefit other researchers since they can use this as their bases for future needs. The methods of synthesizing the silver nanoparticles can be used as one of the basis in synthesizing silver nanoparticles completely.

Professionals. The results of this study would also benefit other professionals who are in the field of Nano science, physics, chemistry, biology, and etc. They can use the methods to prepare the exact size and shape of the silver nanoparticles for their specific purpose.

Society. The society will also benefit the result of this study since the application of silver nanoparticles is broad that it can be commercialized and then directed to the society.

\section{Review of Related Literature}

Synthesized nanomaterial has a wide variety of applications in the field of electronics, photonics, catalysis, medicine, etc. in that case many scientist became interested in the search of the different methods in synthesizing nanomaterial. Green synthesis or the use of plant in synthesizing nanomaterial offers a wide range of benefits over other biological method. According to Ramya and Sylvia (2012) the use of green synthesis method to biosynthesize nanoparticles can avoid the presence of toxic chemical and proven to be better methods over chemical and physical method because of its slower kinetics and is also cost effective, environment friendly, and easily scaled up for large scale synthesis.

Silver nanoparticles, an example of a nanomaterial, have gained significant interest due to their unique optical, antimicrobial, electrical, physical properties and their possible application used in commercial products such as paints and coatings and in medicine. Green synthesis is the best way to synthesized silver nanoparticles, according to Aromal, et al., (2012), plant crude extracts contain novel secondary metabolites such as phenolic acid, flavonoids, alkaloids, and terpenoids, which are mainly responsible for the reduction of ionic metal into bulk metallic nanoparticles and are constantly involved in redox reactions required to synthesize eco-friendly nanoparticles.

According to Ankana, et al., (2010) silver disassembles into particles following the addition of plant extract, which may lead to a color change. Solutions of silver nanoparticles appear dark, yellow-brown in color because of the surface plasmon resonance phenomenon.

Alagaw plant (Premna odorata) is a small hairy tree commonly seen in the forests of the Philippines and its neighboring countries are known to have anti- inflammatory activity and are concluded to have long chain fatty acids in free ester forms (57.18\%) (El- Mudomy, et al., 2105) 
which is a good characteristic of a reducing agent and thus applicable for the synthesis of silver nanoparticles.

Silver nitrate (AgNO3) is an organic compound that is an adaptable progenitor to various other compounds of silver. The silver nitrate reacts with copper to produce silver crystals along with a blue copper nitrate solution.

UV-visible absorbance spectroscopy is very useful and reliable technique for the primary characterization of synthesized nanoparticles which is also used to monitor the stability of silver nanoparticles, it is fast, easy, simple, sensitive, selective for different type of nanoparticles, needs only of a short period of time for measurement, and finally a calibration is not required for particle characterization of colloidal suspensions (Huang, et al., 2007). For the morphology, sized and shape of silver nanoparticles Transmission Electron Microscope is used (Anandaksmi, et al., 2015).

\section{E. Research Design \& Methodology}

Experimental Design and Treatments

This study utilized the Complete Randomized Design (CRD). A single factor experiment with three (3) treatments done in three (3) replications shown in Table 1.

Table 1. Concentration of Alagaw leaf extract for the biosynthesis of Silver Nanoparticles.

Materials

Treatments

\begin{tabular}{cccc} 
& A & B & C \\
\hline Alagaw Leaf & $20 \mathrm{~g}$ & $40 \mathrm{~g}$ & $60 \mathrm{~g}$ \\
Water & $100 \mathrm{~mL}$ & $100 \mathrm{~mL}$ & $100 \mathrm{~mL}$ \\
\hline \hline
\end{tabular}

Experimental Procedure

Collection of Plant Materials

The Alagaw leaves were collected from Surongon Subdivision, Arnaldo Boulevard, Roxas City, Capiz, Philippines and authenticated by the Department of Agriculture.

\section{Extraction - Decoction Method}

A $20 \mathrm{~g}$ of finely cut leaves, for Treatment A, $40 \mathrm{~g}$ of finely cut leaves, for Treatment B, and $60 \mathrm{~g}$ of finely cut leaves, for Treatment $\mathrm{C}$, were thoroughly washed with running tap water to remove dirt and soil respectively. The washed leaves were boiled in $100 \mathrm{~mL}$ water for 15 minutes to get the extract. The cooled extract was filtered using Whatman filter paper No. 1 . The filtrate was collected and stored at $4{ }^{\circ} \mathrm{C}$ for further experiments.

\section{Biosynthesis of Silver Nanoparticles}

Aqueous solution of $225 \mathrm{~mL}$ of $1 \mathrm{mM}$ silver nitrate (AgNO3) was prepared and used for the synthesis of silver nanoparticles. To prepare $225 \mathrm{~mL}$ of the solution, $0.038 \mathrm{~g}$ of silver nitrate was dissolved in $225 \mathrm{~mL}$ water.

$5 \mathrm{~mL}$ of leaf extract with $20 \mathrm{~g}$ of Alagaw leaf for treatment A, 40g of Alagaw leaf for treatment $\mathrm{B}$, and $60 \mathrm{~g}$ of Alagaw leaf for treatment $\mathrm{C}$ during extraction was added and vigorously 
stirred with $25 \mathrm{~mL}$ of aqueous solution of $1 \mathrm{mM}$ silver nitrate in a $100 \mathrm{~mL}$ Erlenmeyer flask for reduction into silver ions and kept at room temperature. The overall reaction process was carried out in a dark place to avoid unnecessary photochemical reactions. After $10 \mathrm{~min}$, the change of the color was noted indicating the formation of silver nanoparticles (Jain, et al., 2009).

\section{Research Instrument}

\section{Characterization of Silver Nanoparticles}

$U V$-vis Spectrophotometry

The reduction of pure silver ions was monitored by measuring the UV-visible spectrum of the reaction mixture at a given time intervals of 10min and $60 \mathrm{~min}$. The biosynthesized silver nanoparticle solution was then subjected to UV-Vis spectral analysis using a UV-Vis Spectrophotometer. The peak shifted in the absorption spectrum from 340 to $620 \mathrm{~nm}$ with increasing reaction time was observed.

\section{Transmission Electron Microscopy (TEM) Analysis}

TEM analysis was done using TEM machine. Thin film of the sample was prepared on a carbon-coated copper grid by just dropping a very small amount of the sample on the grid, extra solution was removed using a blotting paper and then the film on the TEM grid was allowed to dry by putting it under a mercury lamp for $5 \mathrm{~min}$.

\section{F. Results and Discussion}

In terms of the polynomial trend line of the UV-vis absorbance peak of Treatment A within 10 minutes interval, the maximum absorption of the silver nanoparticles solution is at 440 $\mathrm{nm}$ corresponding to the surface Plasmon resonance of silver nanoparticles.

In terms of the polynomial trend line of the UV-vis absorbance peak of Treatment B within 10 minutes interval, the maximum absorption of the silver nanoparticles solution is approximately at $460 \mathrm{~nm}$ corresponding to the surface Plasmon resonance of silver nanoparticles.

In terms of the polynomial trend line of the UV-vis absorbance peak of Treatment $\mathrm{C}$ within 10 minutes interval, the maximum absorption of the silver nanoparticles solution is approximately at $530 \mathrm{~nm}$.

In terms of the polynomial trend line of the UV-vis absorbance peak of Treatment A within 60 minutes interval, the maximum absorption of the silver nanoparticles solution is approximately at $430 \mathrm{~nm}$.

In terms of the polynomial trend line of the UV-vis absorbance peak of Treatment B within 60 minutes interval, the maximum absorption of the silver nanoparticles solution is approximately at $465 \mathrm{~nm}$.

In terms of the polynomial trend line of the UV-vis absorbance peak of Treatment $\mathrm{C}$ within 60 minutes interval, the maximum absorption of the silver nanoparticles solution is approximately at $470 \mathrm{~nm}$.

In terms of UV-vis absorbance spectrum of silver nanoparticles in 10 minutes vs. 60 minutes within $620.0 \mathrm{~nm}-340.0 \mathrm{~nm}$ for Treatment A, red-shift was observed during the reaction. The absorbance increases with the influence of time. Isosbestic points are also seen in the graph. The appearance of these points is used as reference in the study of reaction rates, as the absorbance at those wavelength remains constant throughout the whole reaction.

In terms of UV-vis absorbance spectrum of silver nanoparticles in 10 minutes vs. 60 minutes within $620.0 \mathrm{~nm}-340.0 \mathrm{~nm}$ for Treatment B, red-shift was observed during the reaction. The absorbance after 10 minutes of interval increases with time. 
In terms of UV-vis absorbance spectrum of silver nanoparticles in 10 minutes vs. 60 minutes within $620.0 \mathrm{~nm}-340.0 \mathrm{~nm}$ for Treatment C, blue-shift was observed during the reaction. The absorbance after 10 minutes of interval increases yet the intensity shortens that suggests to the decelerating rate of reaction.

In terms of the effect of the concentration of Alagaw leaf extract on the formation of silver nanoparticles within 10 minutes. The SPR peak observed at around $440 \mathrm{~nm}, 455 \mathrm{~nm}$, and $530 \mathrm{~nm}$ for $20 \mathrm{~g}, 40 \mathrm{~g}$, and $60 \mathrm{~g}$ respectively. With increasing ratio of leaf extract, the concentration of SPR band increased yet particles were not stable and agglomeration was observed.

In terms of the effect of the concentration of Alagaw leaf extract on the formation of silver nanoparticles within 60 minutes. The SPR peak observed at around $430 \mathrm{~nm}, 465 \mathrm{~nm}$, and $475 \mathrm{~nm}$ for $20 \mathrm{~g}, 40 \mathrm{~g}$, and $60 \mathrm{~g}$ respectively. Treatment B and Treatment C gradual red shift from $400 \mathrm{~nm}$ to $460 \mathrm{~nm}$ suggests the formation of smaller monodispersed silver nanoparticles as the concentration of leaf extract increases over time. Both the Treatment shows fast reaction rate than Treatment A as their SPR band width increases.

All the results are in agreement with the earlier investigations conducted by Kantrao (2014) et al., Tripathy (2010) et al., and Jha (2010) et al.

In terms of the average wavelength peaks of replicates in 10 minutes and 60 minutes interval, replicate B3 of Treatment B (40 g) got the highest average wavelength in 10 minutes interval with $597.6 \mathrm{~nm}$. It also acquired the highest average wavelength peaks among all the replicates with $545.8 \mathrm{~nm}$. The stability of the reaction of Treatment A based on the average wavelength shows a slow reaction rate. Treatment $\mathrm{B}$ has faster reaction rate than Treatment $\mathrm{A}$. Treatment $\mathrm{C}$ has the fastest reaction rate among the three treatments.

In terms of the average absorbance peaks of replicates in 10 minutes and 60 minutes interval, replicate A1, C2, and C3 of Treatment A (20 g) and Treatment C (60 g) got the highest average absorbance in 10 minutes and 60 minutes interval with 4 . The stated replicates also acquired the highest average absorbance peaks among all the replicates with 4 .

Treatment $\mathrm{C}$ turns out to be more stable and monodispersed than treatment $\mathrm{B}$ and treatment $\mathrm{A}$ based on the average wavelength and absorbance. Replicate C3 shows the best result among the replicates based on reaction rate and stability. Thus, it was the sample sent for TEM analysis.

In terms of the difference on the effect of the concentration of Alagaw leaf extract on the wavelength peaks of silver nanoparticles in 10 minutes and 60 minutes interval, result shows that there was a significant difference on the wavelength peaks of the synthesized silver nanoparticles treated with different concentration in 10 minutes and 60 minutes interval.

In terms of the difference on the effect of the concentration of Alagaw leaf extract on the absorbance peaks of silver nanoparticles in 10 minutes and 60 minutes interval, result shows that there was no significant difference on the absorbance peaks of the synthesized silver nanoparticles treated with different concentration in 10 minutes and 60 minutes interval.

The TEM analysis of the silver nanoparticles showed that the size of the synthesized silver nanoparticles ranges from 50 to $100 \mathrm{~nm}$ with near spherical in shape.

According to Khodashenas (2015) in his study, nanoparticles having polyhedral, spherical and near spherical shapes are close to equilibrium. This strengthens the latter analysis that Treatment $\mathrm{C}$ is almost in equilibrium due to its wavelength and absorbance peaks which in turn became the basis for the sample to undergo TEM analysis. 


\section{G. Conclusions and Recommendations}

Based on the findings of the study, the following conclusions were formulated:

Alagaw plant can be a good reducing agent for the biosynthesis of silver nanoparticles.

In terms of the effect of the concentration of Alagaw leaf extract on the biosynthesis of silver nanoparticles on the absorbance spectrum in 10 minutes and 60 minutes interval, the SPR peaks increases as the concentration of Alagaw leaf extract increases. In terms of size and shape, higher concentrations show lesser variation of size and shape than lower concentration.

The intensity of the absorbance spectrum rises overtime regardless of the concentration.

With increasing ratio of leaf extract, the concentration of SPR band increased yet particles were not stable and agglomeration was observed. Higher concentration tends to have faster kinetics than lower concentration.

In terms of the average wavelength peaks of silver nanoparticles, higher concentrations of leaf extract tend to gain greater average wavelength. Higher concentrations also tend to undergo blue shift much faster than lower concentration of leaf extract.

In terms of the average absorbance peaks of silver nanoparticles, increase in concentration of leaf extract is also increase in the absorbance peaks of solution.

In terms of the reaction rate of the treatment based on the average wavelength peaks, the greater the concentration, the faster it reaches its equilibrium or the faster its reaction rate.

In terms of the stability of the reaction rate of the treatment based on the absorbance peaks, the greater the concentration, the stable the reaction rate of the solution. However, lesser concentration has the tendency to show stability because of the slow reaction that is taking place.

$0.6 \mathrm{~g} / \mathrm{mL}$ has a greater effect on the wavelength peaks of the solution.

Regardless of concentration, Alagaw leaf extract has the same absorbance effect on the biosynthesis of silver nanoparticles.

Based on the findings, the researchers highly recommend the following:

Use Alagaw leaf extract in the biosynthesis of silver nanoparticles with a concentration of $0.6 \mathrm{~g} / \mathrm{mL}$ for effective result.

Determine the maximum Surface Plasmon Resonance concentration of the Alagaw leaf extract to standardize the stabilization of the reaction.

Increase the concentration of the extract to obtain monodispersed size nanoparticles.

Increase the time interval of the UV-vis spectroscopy to determine the stable absorbance spectrum of the solution.

Increase the concentration of the extract to have a faster and stable reaction rate towards equilibrium. Also, improve other parameters to control the reaction rate during synthesis.

It is recommended to use $0.6 \mathrm{~g} / \mathrm{mL}$ of Alagaw leaf extract in the biosynthesis of silver nanoparticles since it is more effective in terms of wavelength peaks.

Use other characterization techniques to improve the physical and chemical properties of silver nanoparticles.

Undergo phytochemical analysis and FTIR scan to prove the role of biomolecules in the biosynthesis of silver nanoparticles.

Undergo microbial assay and inhibitory effect to prove the antibacterial property of the synthesized silver nanoparticles.

\section{H. Outputs and Deliverable}




\section{Literature Cited/Bibliography}

Ahmad, N., Sharma, S. "Green Synthesis of Silver Nanoparticles Using Extracts of Ananas comusus" (2012)http://file.scirp.org/pdf/GSC20120400003_16186171.pdf Date Retrieved: October 26, 2017

Ahmed, S., Ahmad, M., Swami, B. L., \& Ikram, S. (2015). A review on plants extract mediated synthesis of silver nanoparticles for antimicrobial applications: A green expertise. Journal of advanced research, 7(1), 17-28.

Ajitha B, Reddy YAK, Reddy PS. (2015) Green synthesis and characterization of silver nanoparticles using Lantana camara leaf extract. Mater Sci Eng C. 2015;49:373-381. doi: 10.1016/j.msec.2015.01.035.

Alexandrova K, Markova-Deneva I, Gigova A, Dragieva I (2008) In: Dimov S, Menz W (eds) TEM/SEM and FT-IR characterization of biocompatible magnetic nanoparticles. Multi-Material Micro Manufacture, pp 1-4, Cardiff University, Cardiff, UK: Published by Whittles Publishing Ltd.

Anandaksmi, K., Venugobal, J., Ramasamy, V., (2015) "Characterization silver nanoparticles by green synthesis method using Pedalium murex leaf extract and their antibacterial activity" https://link.springer.com/article/10.1007s13204-015-0449-z Date Retrieve: March 18, 2018

Ankanna S, Prasada TNVKV, Elumalai EKB, Savithramma N. (2010) Production of biogenic silver nanoparticles using Boswellia ovalifoliolata stem bark. Dig J Nanomater Biostruct. 2010;5:369-372.

Amjadi M., Farzampour L., (2014) Fluorescence quenching of fluoroquinolones by gold nanoparticles with different sizes and its analytical application. J Luminesc 145: 263268.

Arockia John Paul, J., Karunai Selvi, B. \& Karmegam, N. Appl Nanosci (2015) 5: 937. https://doi.org/10.1007/s13204-014-0397-z Date Retrieved: October 25, 2017

Aromal SA, Philip D. (2012) Green synthesis of gold nanoparticles using Trigonella foenumgraecum and its size dependent catalytic activity. Spectrochim Acta A. 2012;97:1-5. doi: 10.1016/j.saa.2012.05.083.

Ashokkumar S., Ravi S., Kathiravan V., Velmurugan S. (2015) Synthesis of silver nanoparticles using A. indicum leaf extract and their antibacterial activity, Spectrochim. Acta Part A Mol. Biomol. Spectrosc. 134 (2015) 43-39.

Bai HJ, Zhang ZM, Guo Y, Yang GE. (2009) Biosynthesis of cadmium sulfide nanoparticles by photosynthetic bacteria Rhodopseudomonas palustris. Colloids Surf B Biointerf. 2009;70:142-146. doi: 10.1016/j.colsurfb.2008.12.025.

Chen, D., et al. J Mater Sci (2009) 44: 1076. https://doi.org/10.1007/s10853-008-3204-y Date Retrieved: December 22, 2017

Chernousova S., Epple M. (2013) Silver as antibacterial agent: Ion, nanoparticle, and metal. Angew. Chem. Int. Ed. 2013; 52:1636-1653. Doi: 10.1002/annie.201205923.

Choosing the best trendline for your data. https://support.office.com/en-us/article/choosing-thebest-trendline-for-your-data-1bb3c9e7-0280-45b5-9ab0-d0c93161daa8 Date Retrieved: June 26, 2018

Das, R., Nath S.S., Chakdar, D., Gope, G., Bhattacharjee, R. (2009) Presentation of silver nanoparticles and their characterization. J. Nanotechnol. 2009;5:1-6 
Dubey SP, Lahtinen M, Särkkä H, Sillanpää M. (2010) Bioprospective of Sorbus aucuparia leaf extract in development of silver and gold nanocolloids. Colloid Surf B. 2010;80:2633. doi: 10.1016/j.colsurfb.2010.05.024.

Dwivedi AD, Gopal K. (2010) Biosynthesis of gold and silver nanoparticles using Chenopodium album leaf extract. Coll Surf A. 2010;369(1-3):27-33. doi: 10.1016/j.colsurfa.2010.07.020.

El-Mudomy, A., et al. World journal of pharmacy and pharmaceutical sciences (2015) 5, Issue 1, 129-135

Giljohann DA., Seferos DS., Daniel WL., Massich MD., Patel PC., et al. (2010) Gold nanoparticles for biology and medicine. AngewChemInt Ed Engl 49: 3280-3294.

Gurunathan S., Park J.H., Han J.W., Kim J.H. (2015) Comparative assessment of the apoptotic potential of silver nanoparticles synthesized by Bacillus tequilensis and Calocybe indica in MDA-MB-231 human breast cancer cells: Targeting p53 for anticancer therapy. Int. J. Nanomed. 2015; 10:4203-4222. Doi: 10.2147/IJN.S83953

Huang, X.H., Jain, P.K., El-Sayed, M.A. (2007) Gold nanoparticles: Interesting optical properties and recent applications in cancer diagnostic and therapy. Namomed. Lond. 2007;2:681-693. doi:10.2217\17435889.2.5.681

Houck, M., PhD, Siegel, J., PhD (2015) Fundamentals of Forensic Science. Third Edition:Chapter 5- Light and Matter. Page 93-199

Iravani S, Zolfaghari B. (2013) Green synthesis of silver nanoparticles using Pinus eldarica bark extract. BioMed Res Int. 2013;2013:639725. doi: 10.1155/2013/639725.

Jha K.A., Prasad K., (2010) Green synthesis of silver nanoparticles using Cyas leaf. Int. J. Green Nanotechnol. Phy. Chem. 1(2), 110-117.

Kantrao S., Balaji S., Basavraja S., Kamala J., Venkataraman A., (2014) Biosynthesis and characterization of silver nanoparticles using Ficus benghalensis leaf extract. International Journal of Research in Engineering and Technology (IJRET). Volume: 03 Issue:

Khalid, A., Tawfik AS., (2016) Gold and Silver Nanoparticles: Synthesis Methods, Characterization Routes and Applications towards Drugs https://www.omicsonline.org/open-access/gold-and-silver-nanoparticles-synthesismethods-characterizationroutes-and-applications-towards-drugs-2161-05251000384.php?aid=76676\#46. Date Retrieved: November 10, 2017

Kim, J-K,.et al. (2008) Effect of CNT decoration with silver nanoparticles on electrical conductivity of CNTpolymercompositeshttps://doi.org/10.1016/j.carbon.2008.06.048:Date Retrieve: December 22, 2017

Korbekandi H, Iravani S, Abbasi S. (2009) Production of nanoparticles using organism's production of nanoparticles using organisms. Critical Rev Biotechnol. 2009;29(4):279-306. doi: 10.3109/07388550903062462.

Kuppusamy, P., Ichwan, S.J., Parine, N.R., Yusoff, M.M., Maniam, G.P., Govindan, N. (2015) Intracellular biosynthesis of $\mathrm{Au}$ and $\mathrm{Ag}$ nanoparticles using ethanolic extract of Brassica oleracea L. and studies on their physiochemical and biological properties. J. Environ. Sci 29, 151-157

Krutyakov YA., Kudrinskiy AA., Olenin AY., Lisichkin GV., (2008) Synthesis and properties of silver nanoparticles: advances and prospects. Russian Chemical Reviews 77: 233257. 
Li S, Shen Y, Xie A, Yu X, Qiu L, Zhang L, Zhang Q. (2007) Green synthesis of silver nanoparticles using Capsicum annuum L. extract. Green Chem. 2007;9:852-858. doi: $10.1039 / \mathrm{b} 615357 \mathrm{~g}$.

Lin, P.C., Lin, S., Wang, P.C., Sridhar, R. (2014) Techniques for physicochemical characterization of nanomarterials. Biotechnol. Adv. 2014;32:711-726. doi:10.1016/j.biotechadv.2013.11.006

Lu AH., Salabas EL., Schuth F., (2007) Magnetic nanoparticles: synthesis, protection, functionalization, and application. AngewandteChemie46: 1222-1244.

Montoya, I.J. (2012). The antinociceptive and anti-inflammatory activities of the methanolic extract of the leaves of Premna odorata blanco (Verbenaceae).University of Santo Tomas

Murawala P., Tirmale A., Shiras A., Prasad, BL., (2014) In situ synthesized BSA capped gold nanoparticles: effective carrier of anticancer drug methotrexate to MCF-7 breast cancer cells. Mater SciEng C Mater BiolAppl 34: 158-167.

Nath, S.S., Gope, D.G. (2007) Synthesis of CdS and ZnS quantum dots and their applications in Electrons. Nano Trends. 2007;2:20-28

Nestor, A.R.V., Mendieta, V.S., Lopez, M.A.C, Espinosa, R.M.G, Lopez, M.A.C., Alatorre, J.A.A, 200888... solventless synthesis and optical properties of $\mathrm{Au}$ and $\mathrm{Ag}$ nanoparticles using Camiellia sinensis extract. Mater. Lett. 62, 3103-3105

Oldenburg, $\quad$ S. Silver Nanoparticles: Properties and Applications.https://www.sigmaaldrich.com/technicaldocuments/articles/materialssci ence/nanomaterials/silver-nanoparticles.html. Date retrieved: September 30, 2017

Rai, M., Yadav, A., Gade, A. (2008) CRC 675-Cuttent trends in photosynthesis of metal nanoparticles. Crit Rev Biotechnol 28:277-284

Ramya, M., Sylvia, M. (2012) Green Synthesis of Silver Nanoparticles.https://pdfs.semanticscholar.org/971f/4a342726898d086f7c261b5deed 7eea2f13e.pdf Date Retrieved: October 27, 2017

Shameli K, Ahmad M, Al-Mulla EAJ, Ibrahim NA, et al. (2012) Green biosynthesis of silver nanoparticles using Callicarpa maingayi stem bark extraction. Molecules. 2012;17:8506-8517. doi: 10.3390/molecules17078506.

Suriyakalaa U, Antony JJ, Suganya S, Siva D, Sukirtha R, Kamalakkannan S, Pichiah T, Achiraman S. (2013) Hepatocurative activity of biosynthesized silver nanoparticles fabricated using Andrographis paniculata. Coll Surf B. 2013;102:189-194. doi: 10.1016/j.colsurfb.2012.06.039.

Tripathy A., Raichur A.M., Chandrasekaran N., Prathna T.C., Mukherjee A., (2010) Process variables in biomimetic synthesis of silver nanoparticles by aqueous extract of Azadirachtia indica

Veerasamy R, Xin TZ, Gunasagaran S, Xiang TFW, Yang EFC, Jeyakumar N. (2011) Biosynthesis of silver nanoparticles using mangosteen leaf extract and evaluation of their antimicrobial activities. J Saudi Chem Soci. 2011;15(2):113-120. doi: $10.1016 /$ j.jscs.2010.06.004.

Zhang, H., Wu, M., Sen, A., (2012) In: Nano-Antimicrobials: Silver Nanoparticle Antimicrobials and Related Materials. Clioffi, N., Rai, M., editor. New York: Springer;. pp. 3-45

Zhang, X. F., Liu, Z. G., Shen, W., \& Gurunathan, S. (2016). Silver Nanoparticles: Synthesis, Characterization, Properties, Applications, and Therapeutic Approaches. International journal of molecular sciences, 17(9), 1534. doi:10.3390/ijms17091534 


\section{APPENDICES}

A. UV-vis Absorbance Spectrum of AgNPs in 10 minutes interval within $620.0 \mathrm{~nm}$ $340.0 \mathrm{~nm}$

a. Polynomial trend line of the UV-vis absorbance peak of Treatment A $(0.2$ $\mathrm{g} / \mathrm{mL}$ ) considering all the replicates within 10 minutes interval ranging from $620.0 \mathrm{~nm}-340.0 \mathrm{~nm}$

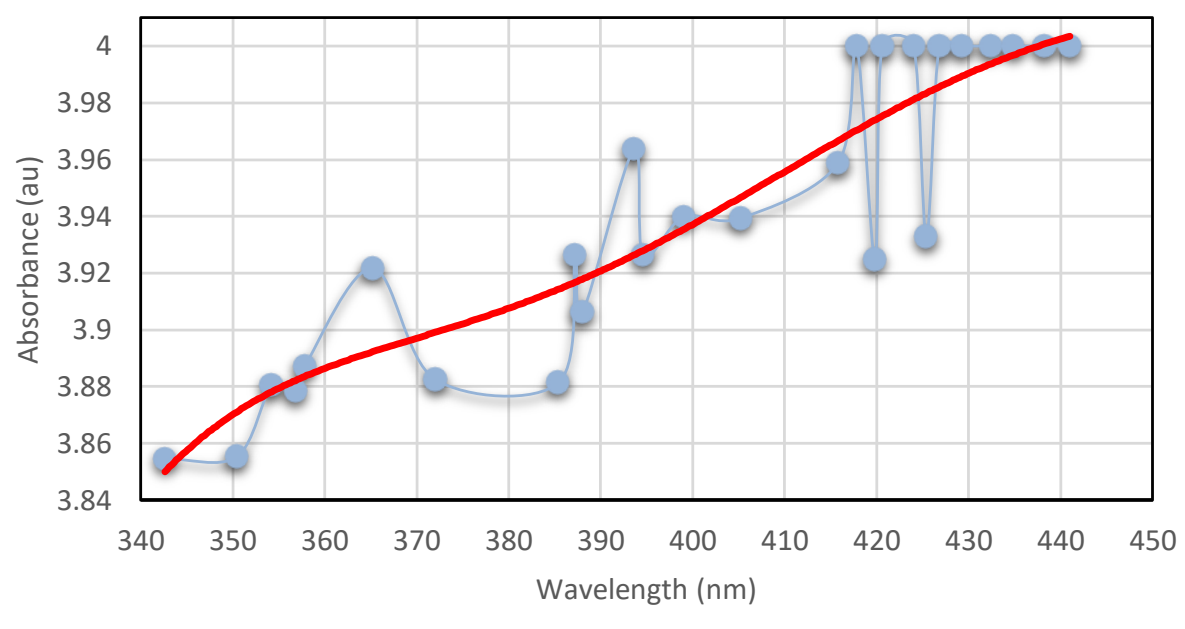

- Absorbance of Treatment A Poly. (Absorbance of Treatment A)

b. Polynomial trend line of the UV-vis absorbance peak of Treatment B $(0.4$ $\mathrm{g} / \mathrm{mL}$ ) considering all the replicates within 10 minutes interval ranging from $620.0 \mathrm{~nm}-340.0 \mathrm{~nm}$

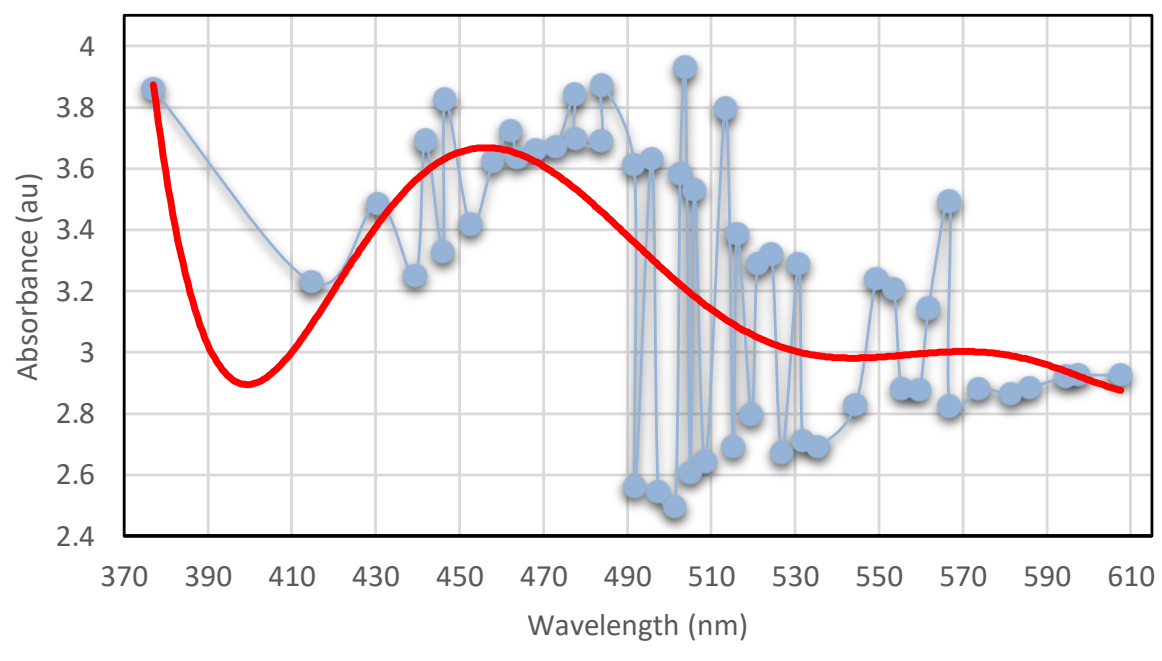

- Absorbance of Treatment B Poly. (Absorbance of Treatment B) 
c. Polynomial trend line of the UV-vis absorbance peak of Treatment $\mathbf{C}(\mathbf{0 . 6}$ $\mathrm{g} / \mathrm{mL}$ ) considering all the replicates within 10 minutes interval ranging from $620.0 \mathrm{~nm}-340.0 \mathrm{~nm}$

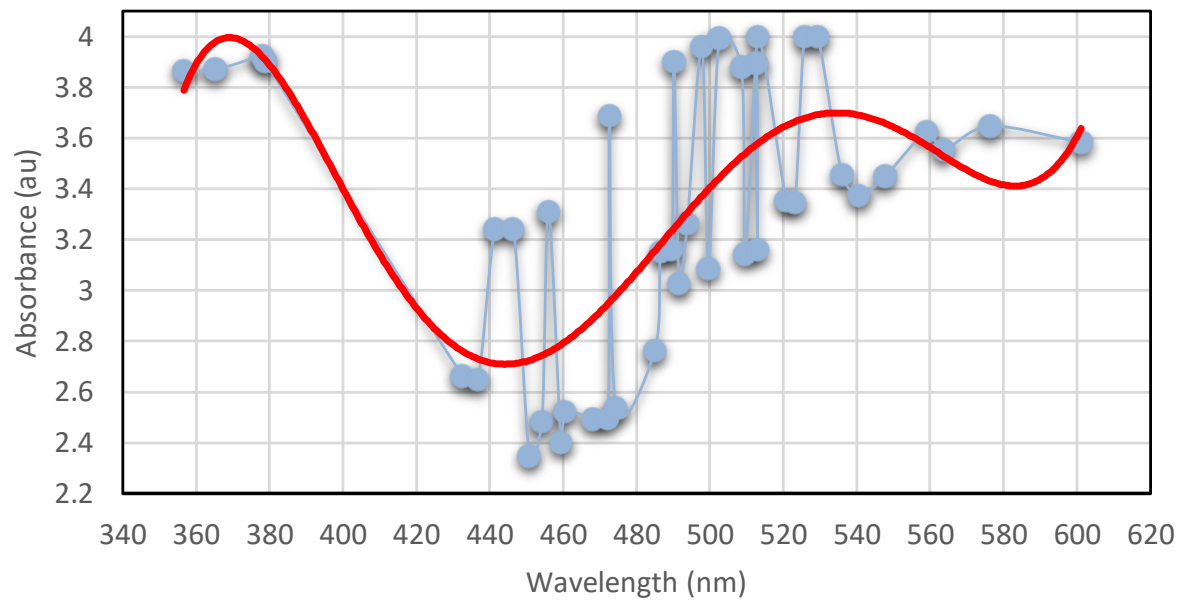

- Absorbance of Treatment C Poly. (Absorbance of Treatment C)

B. UV-vis Absorbance Spectrum of Silver Nanoparticles in 60 minutes interval within $620.0 \mathrm{~nm}-340.0 \mathrm{~nm}$

a. Polynomial trend line of the UV-vis absorbance peak of Treatment A (0.2 $\mathrm{g} / \mathrm{mL}$ ) considering all the replicates within 60 minutes interval ranging from $620.0 \mathrm{~nm}-340.0 \mathrm{~nm}$

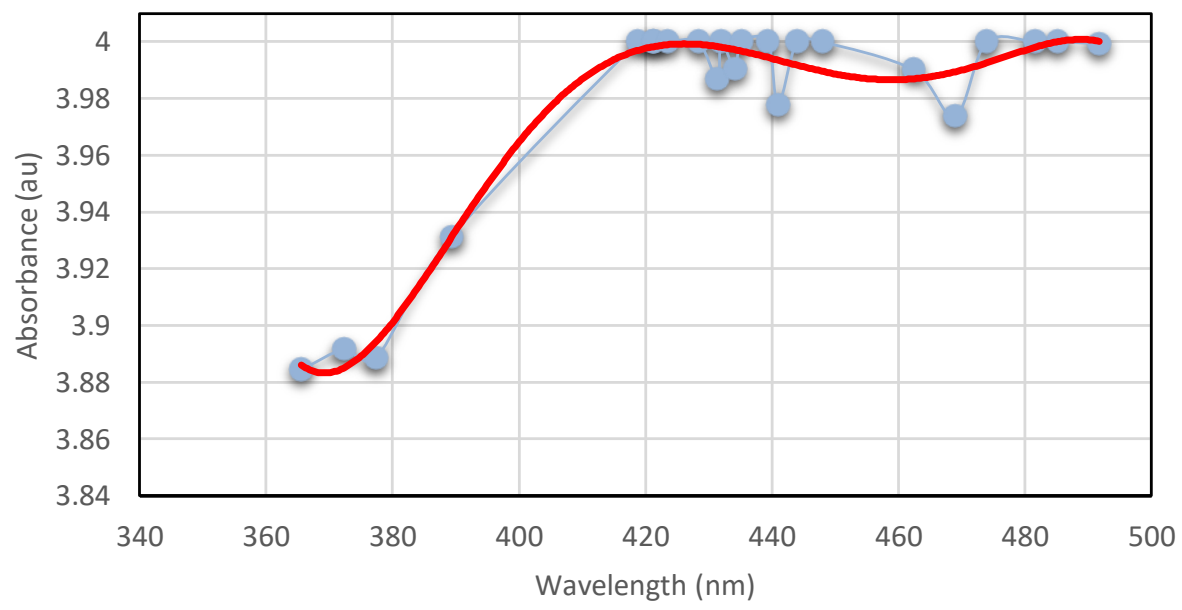

$\longrightarrow$ - Absorbance of Treatment A Poly. (Absorbance of Treatment A) 
b. Polynomial trend line of the UV-vis absorbance peak of Treatment B (0.4 $\mathrm{g} / \mathrm{mL}$ ) considering all the replicates within 60 minutes interval ranging from $620.0 \mathrm{~nm}-340.0 \mathrm{~nm}$

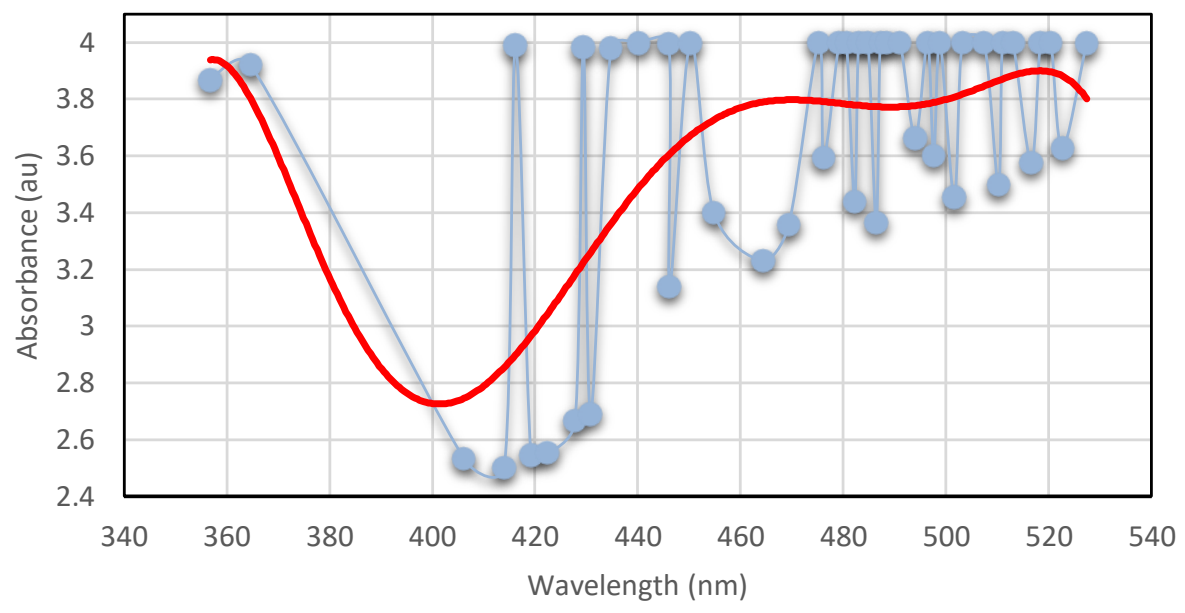

—- Absorbance of Treatment B —Poly. (Absorbance of Treatment B)

c. Polynomial trend line of the UV-vis absorbance peak of Treatment C (0.6 $\mathrm{g} / \mathrm{mL}$ ) considering all the replicates within 60 minutes interval ranging from $620.0 \mathrm{~nm}-340.0 \mathrm{~nm}$

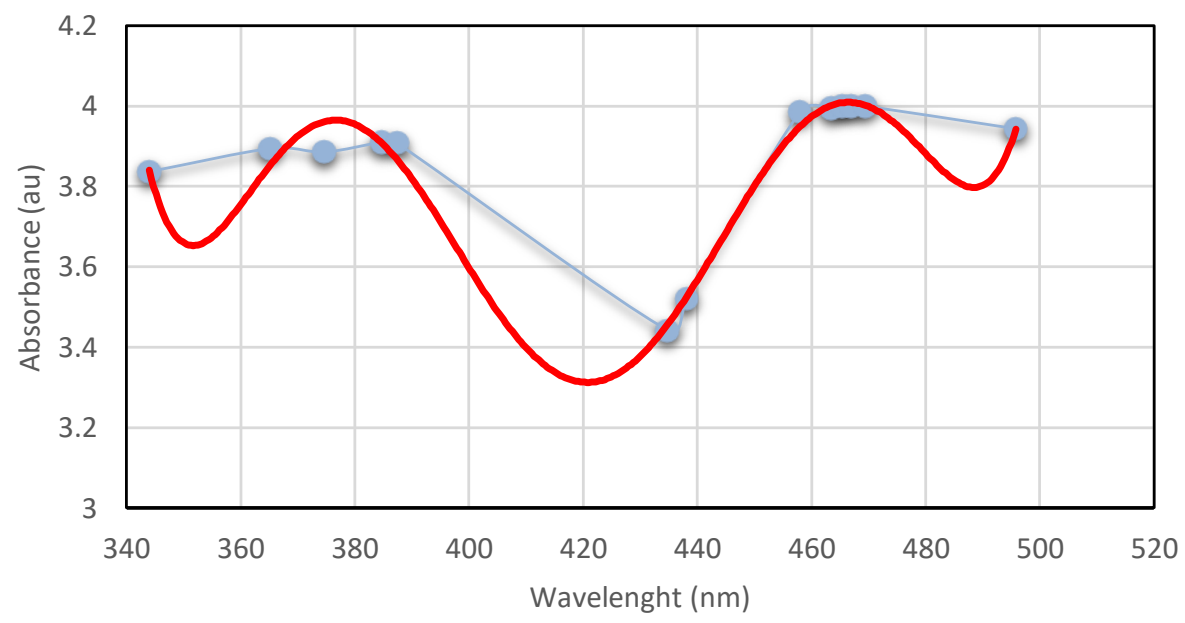

- Absorbance of Treatment C Poly. (Absorbance of Treatment C) 
C. Comparison of Absorbance Spectrum in 10 minutes vs. 60 minutes within $620.0 \mathrm{~nm}$ $-340.0 \mathrm{~nm}$ of each Treatments

a. Polynomial trend line of the UV-vis absorbance peak of Treatment A (0.2 $\mathrm{g} / \mathrm{mL}$ ) considering all the replicates within 10 minutes vs. 60 minutes interval

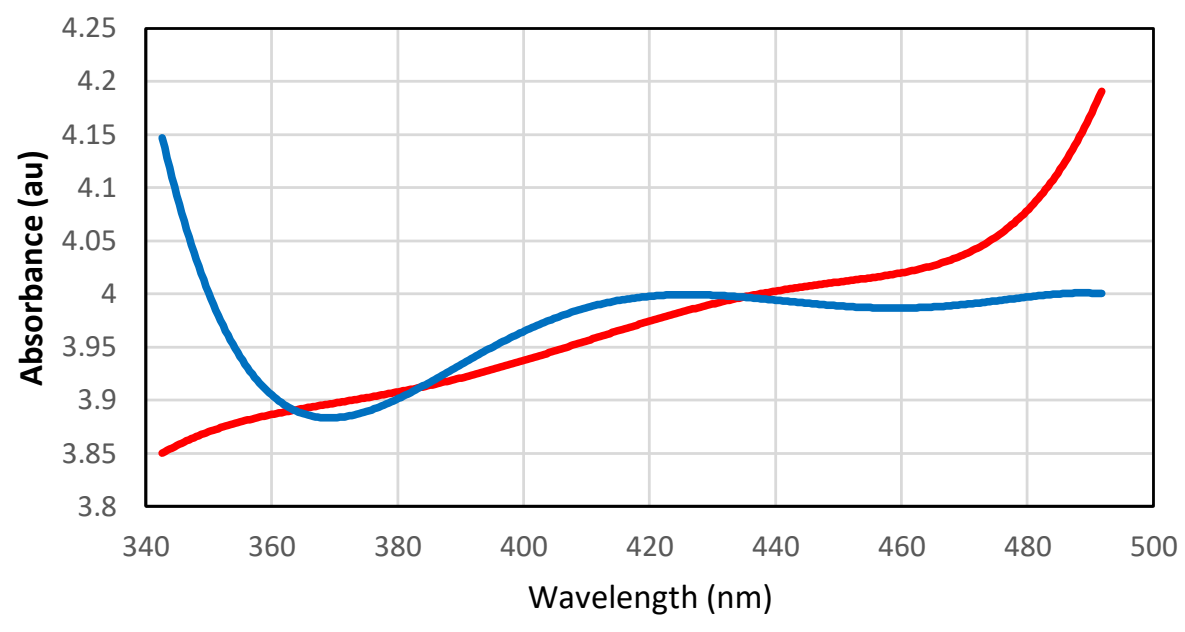

$\longrightarrow$ Poly. (10 minutes) $\quad$ Poly. (60 minutes)

b. Polynomial trend line of the UV-vis absorbance peak of Treatment B (0.4 $\mathrm{g} / \mathrm{mL}$ ) considering all the replicates within 10 minutes vs. 60 minutes interval

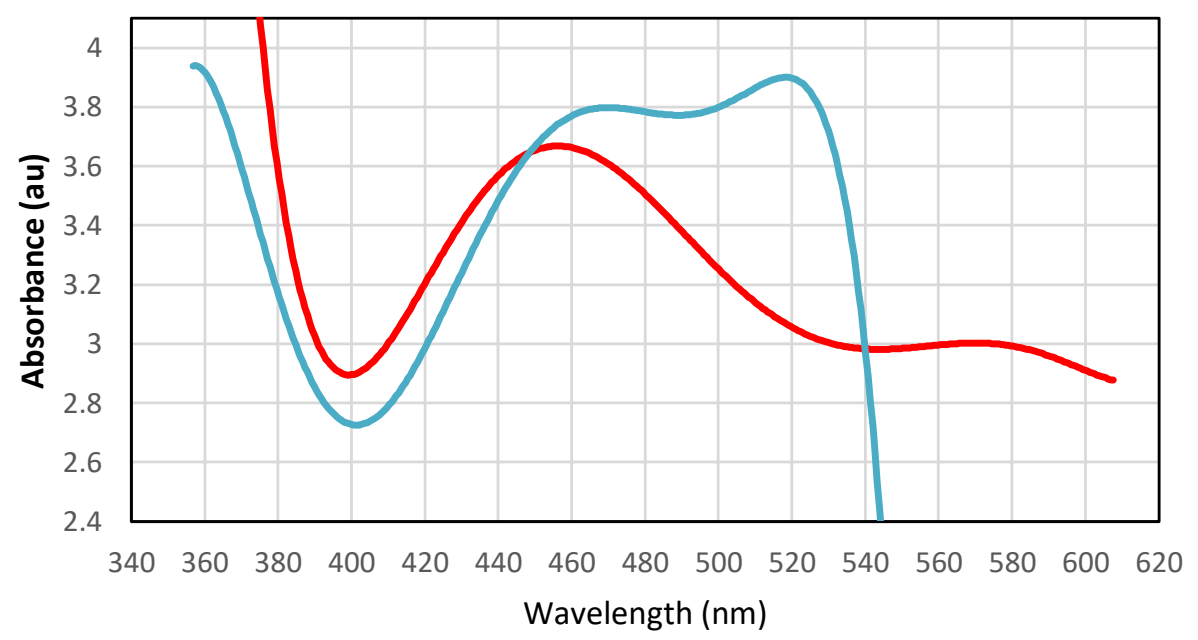

$\longrightarrow$ Poly. (10 minutes) —Poly. (60 minutes) 
c. Polynomial trend line of the UV-vis absorbance peak of Treatment $\mathbf{C}(0.6$ $\mathrm{g} / \mathrm{mL}$ ) considering all the replicates within 10 minutes vs. 60 minutes interval

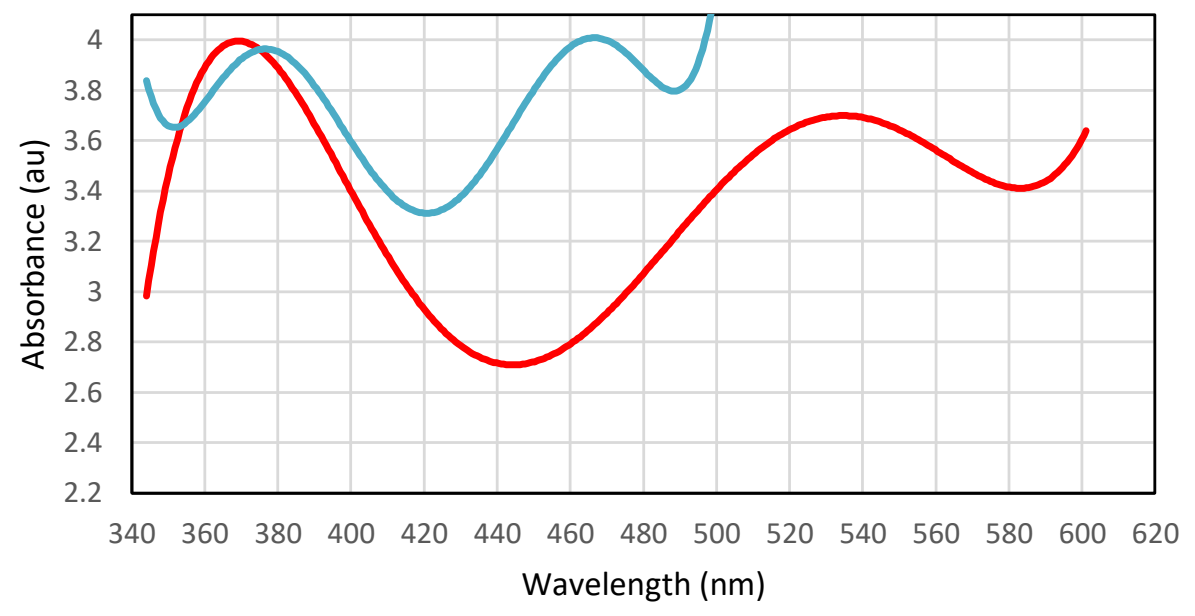

Poly. (10 minutes) Poly. (60 minutes)

D. Comparison of Absorbance Spectrum in 10 minutes within $620.0 \mathrm{~nm}-340.0 \mathrm{~nm}$ of the Treatments

a. Polynomial trend line of the UV-vis absorbance peak recorded at different concentration after $\mathbf{1 0}$ minutes of reaction time

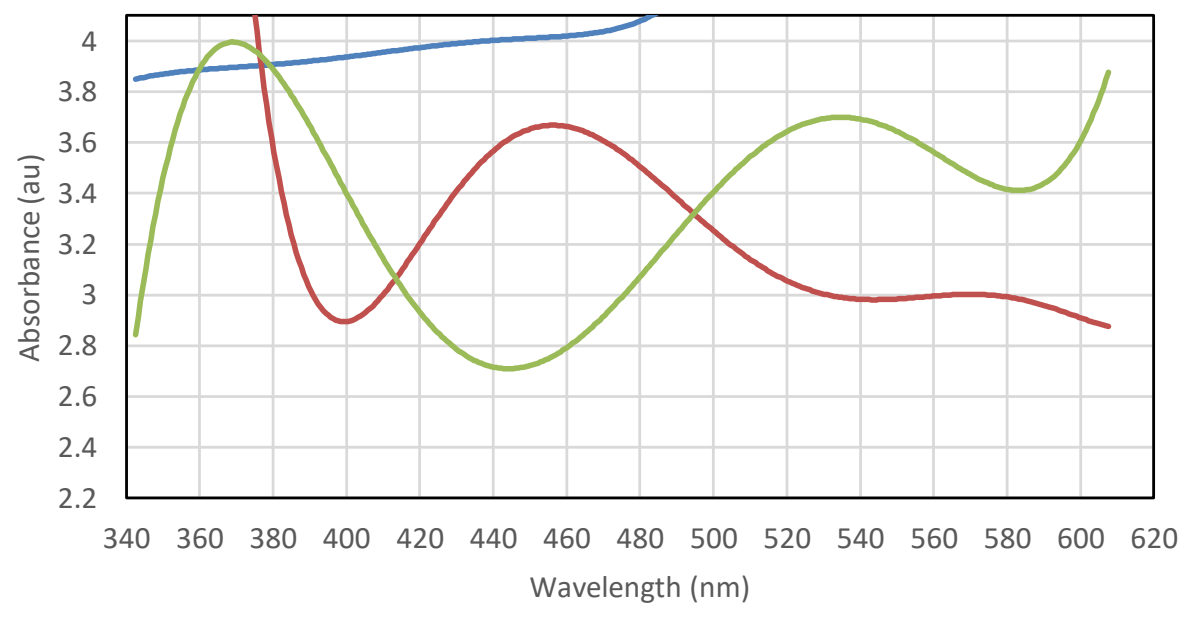

Poly. (A) Poly. (B) Poly. (C) 
E. Comparison of Absorbance Spectrum in 60 minutes within $620.0 \mathrm{~nm}-340.0 \mathrm{~nm}$ of the Treatments

a. Polynomial trend line of the UV-vis absorbance peak recorded at different concentration after 60 minutes of reaction time

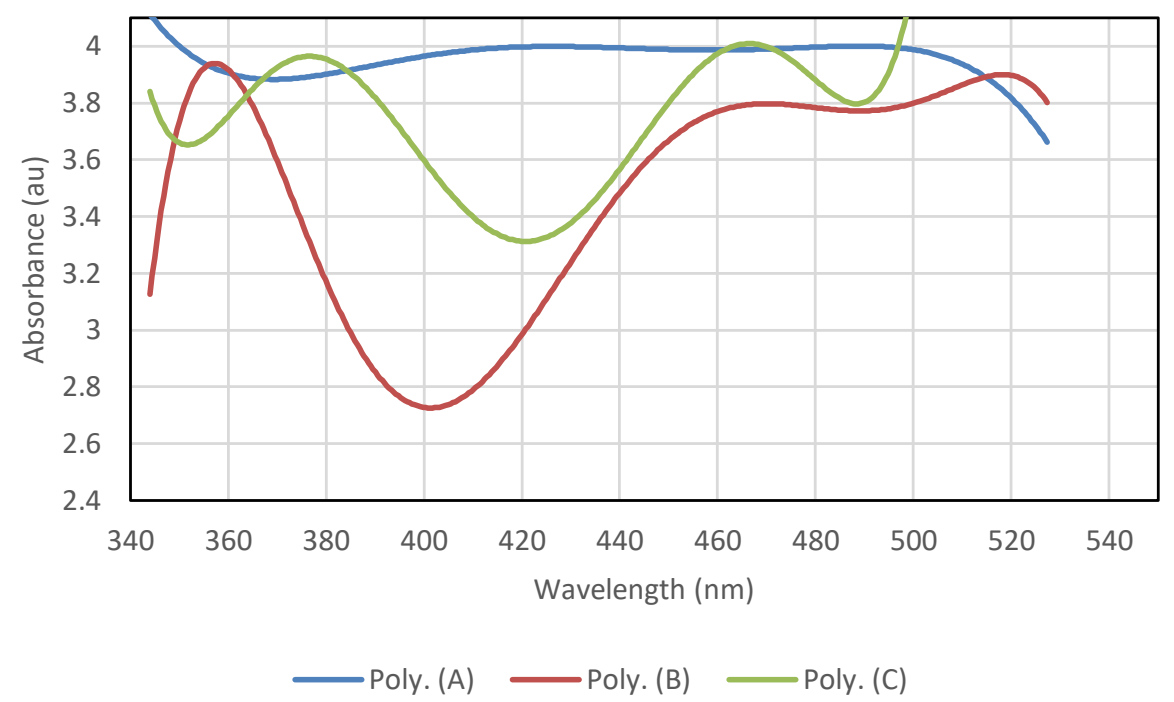

F. Average Wavelength Peaks of replicates in 10 minutes and 60 minutes interval

a. Average wavelength peaks of replicates within 10 minutes and 60 minutes interval

\begin{tabular}{ccccc}
\hline \multicolumn{2}{c}{$\begin{array}{c}\text { Treatments and } \\
\text { Replicates }\end{array}$} & 10 minutes & 60 minutes & $\begin{array}{c}\text { Average } \\
\text { Wavelength }\end{array}$ \\
\hline Treatment A & A1 & $429.4 \mathrm{~nm}$ & $462.0 \mathrm{~nm}$ & $445.7 \mathrm{~nm}$ \\
(0.2 $\mathbf{g} / \mathbf{m L})$ & A2 & $415.8 \mathrm{~nm}$ & $434.2 \mathrm{~nm}$ & $425.0 \mathrm{~nm}$ \\
& A3 & $399.0 \mathrm{~nm}$ & $430.3 \mathrm{~nm}$ & $414.6 \mathrm{~nm}$ \\
Treatment B & B1 & $477.6 \mathrm{~nm}$ & $492.1 \mathrm{~nm}$ & $484.9 \mathrm{~nm}$ \\
(0.4 g/mL) & B2 & $503.8 \mathrm{~nm}$ & $493.5 \mathrm{~nm}$ & $498.6 \mathrm{~nm}$ \\
& B3 & $597.6 \mathrm{~nm}$ & $494.0 \mathrm{~nm}$ & $545.8 \mathrm{~nm}$ \\
Treatment C & C1 & $576.4 \mathrm{~nm}$ & $495.8 \mathrm{~nm}$ & $536.1 \mathrm{~nm}$ \\
(0.6 g/mL) & C2 & $513.0 \mathrm{~nm}$ & $465.4 \mathrm{~nm}$ & $489.2 \mathrm{~nm}$ \\
\hline \hline
\end{tabular}


b. Average wavelength peak of Treatment A replicates within 10 minutes and 60 minutes interval

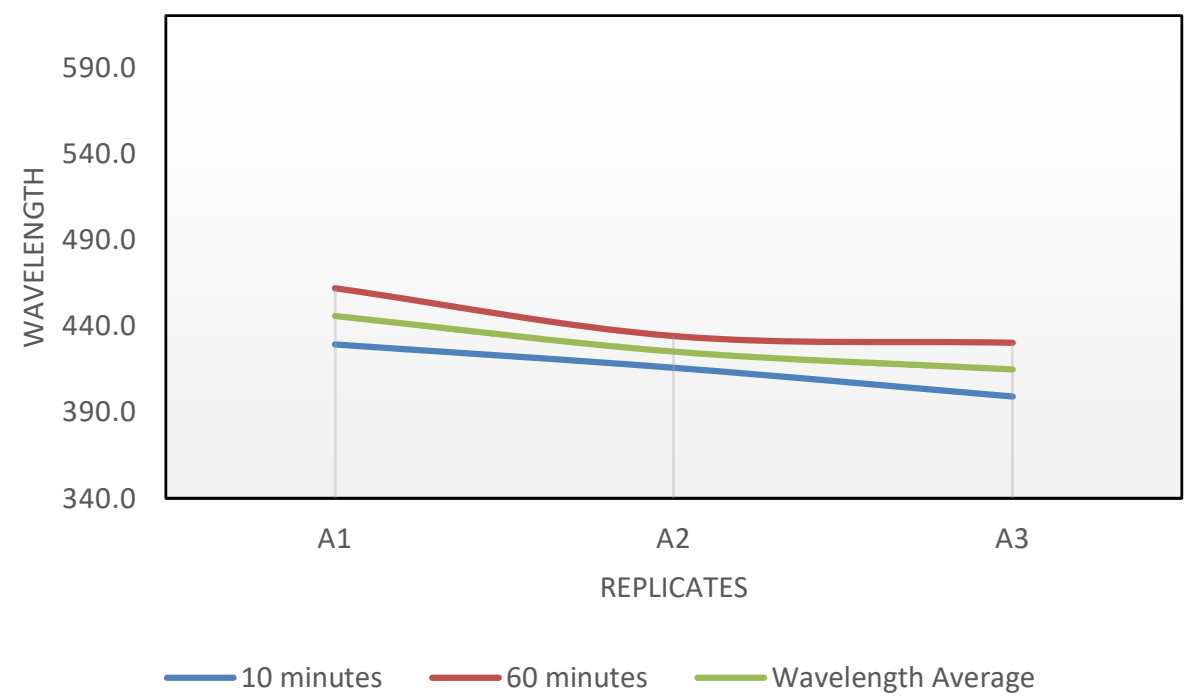

c. Average wavelength peak of Treatment $B$ replicates within 10 minutes and 60 minutes interval

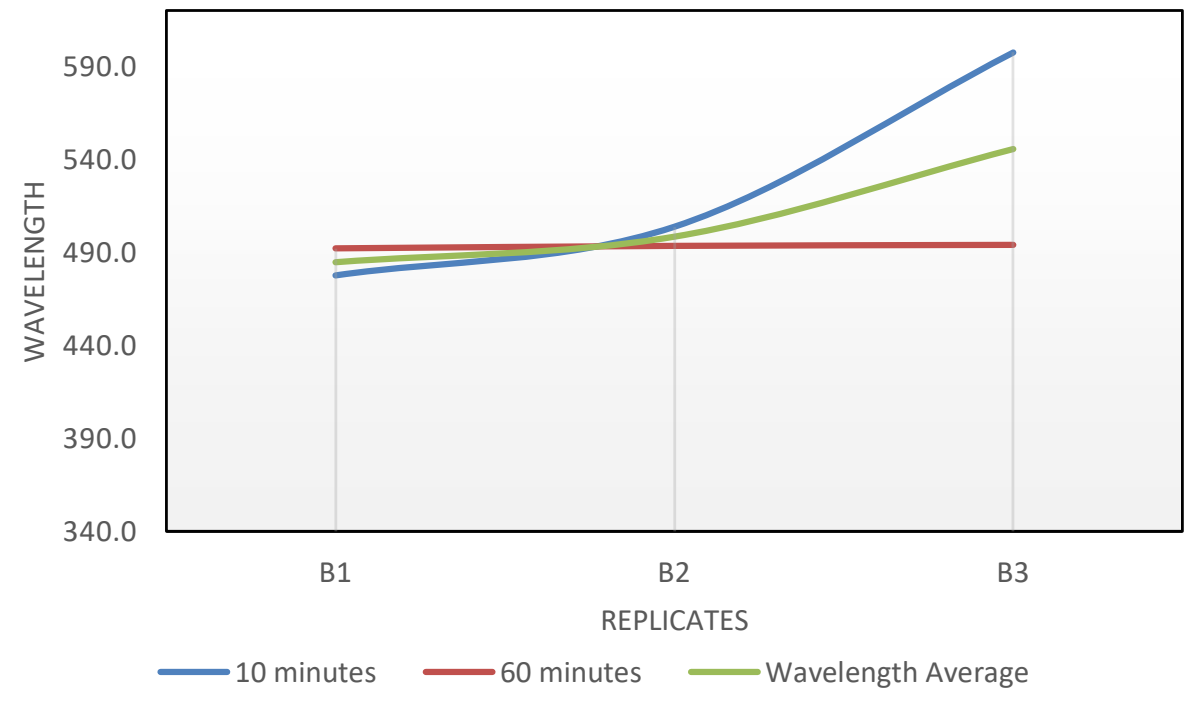

Page 17 of 25 
d. Average wavelength peak of Treatment A replicates within 10 minutes and 60 minutes interval

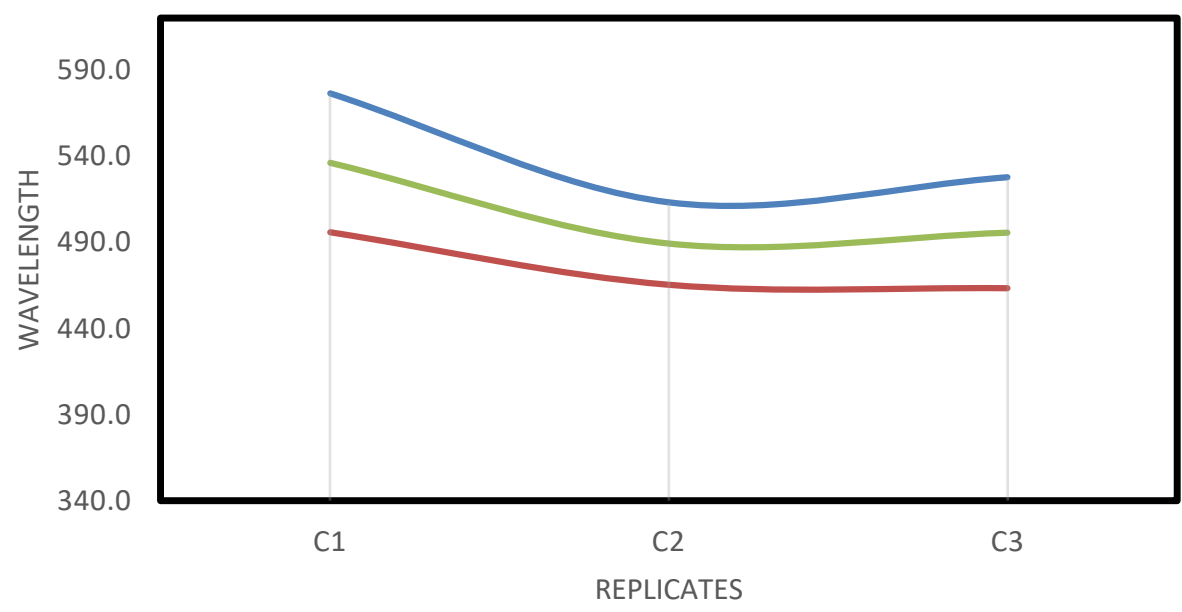

10 minutes $\quad 60$ minutes $\quad$ Wavelength Average

G. Average Absorbance Peaks of replicates in 10 minutes and 60 minutes interval

a. Average absorbance peaks of replicates within 10 minutes and 60 minutes interval

\begin{tabular}{ccccc}
\hline \multicolumn{2}{c}{$\begin{array}{c}\text { Treatments and } \\
\text { Replicates }\end{array}$} & 10 minutes & 60 minutes & $\begin{array}{c}\text { Average } \\
\text { Absorbance }\end{array}$ \\
\hline $\begin{array}{c}\text { Treatment A } \\
\text { (0.2 } \mathrm{g} / \mathrm{mL})\end{array}$ & A2 & 3.9588 & 3.9906 & 4 \\
& A3 & 3.9399 & 4 & 3.9747 \\
Treatment B & B1 & 3.6975 & 4 & 3.97 \\
(0.4 g/mL) & B2 & 3.9303 & 4 & 3.8488 \\
Breatment C & C1 & 3.6479 & 3.9432 & 3.9652 \\
(0.6 $\mathrm{g} / \mathrm{mL})$ & C2 & 4 & 4 & 3.2938 \\
\hline \hline
\end{tabular}


b. Average absorbance peak of Treatment A replicates within $\mathbf{1 0}$ minutes and 60 minutes interval

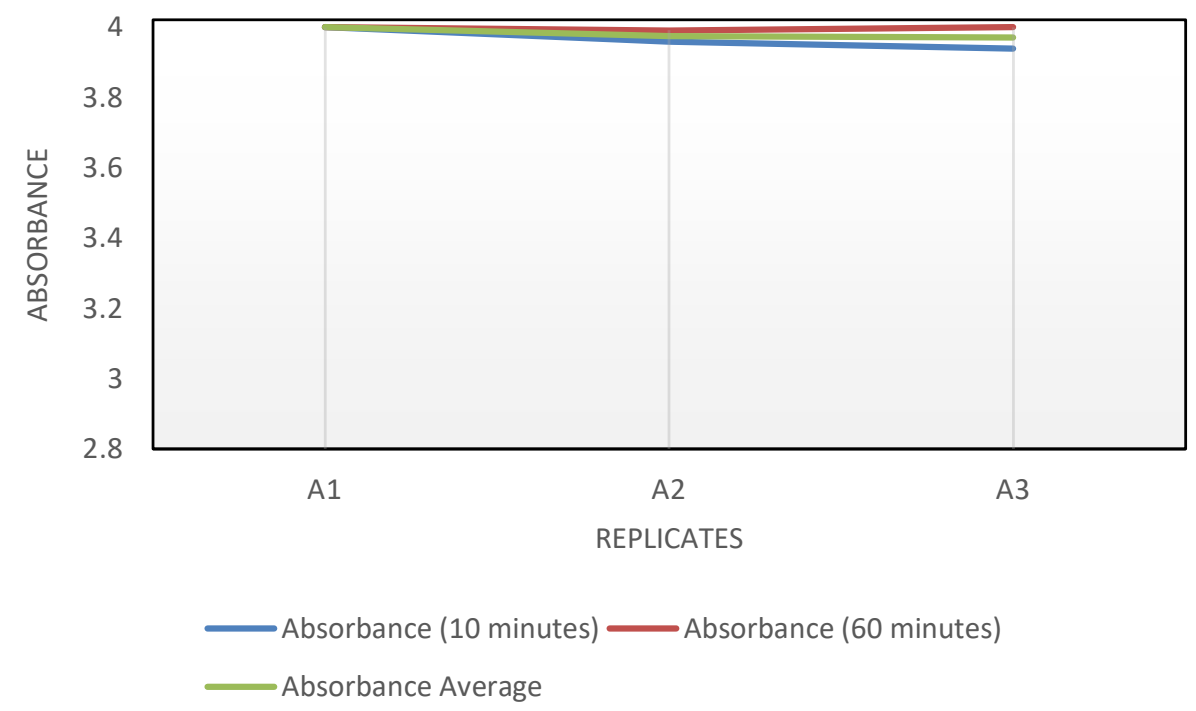

c. Average absorbance peak of Treatment $\mathbf{B}$ replicates within $\mathbf{1 0}$ minutes and 60 minutes interval

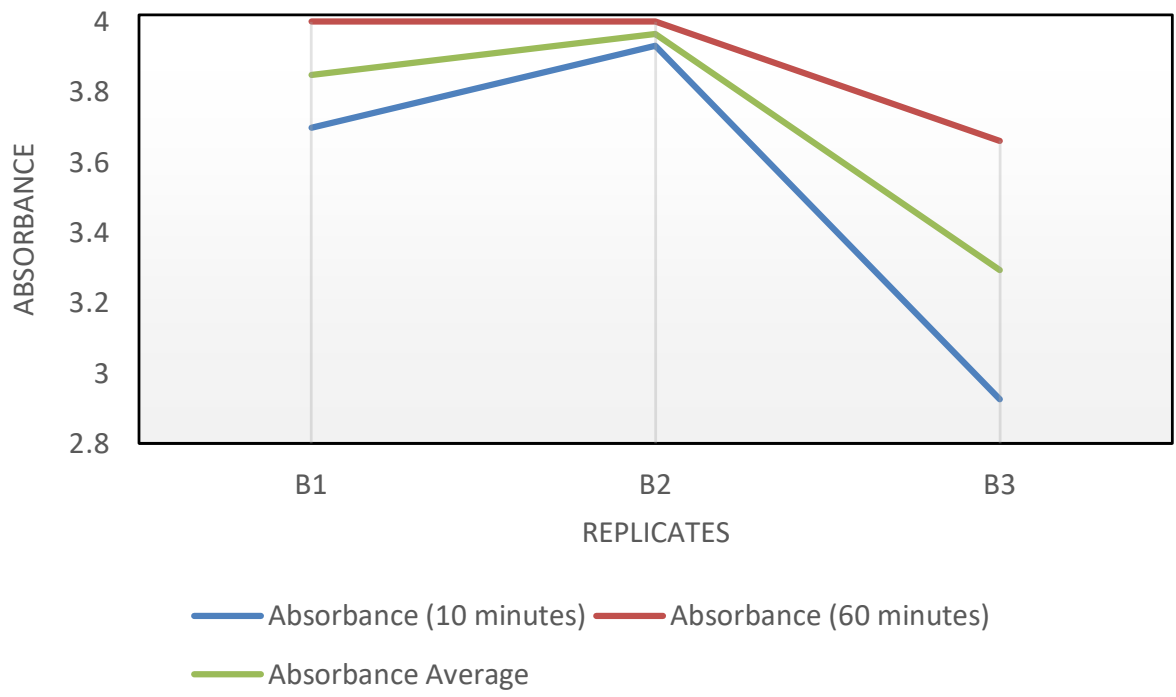

Page 19 of 25 
d. Average absorbance peak of Treatment $\mathrm{C}$ replicates within 10 minutes and 60 minutes interval

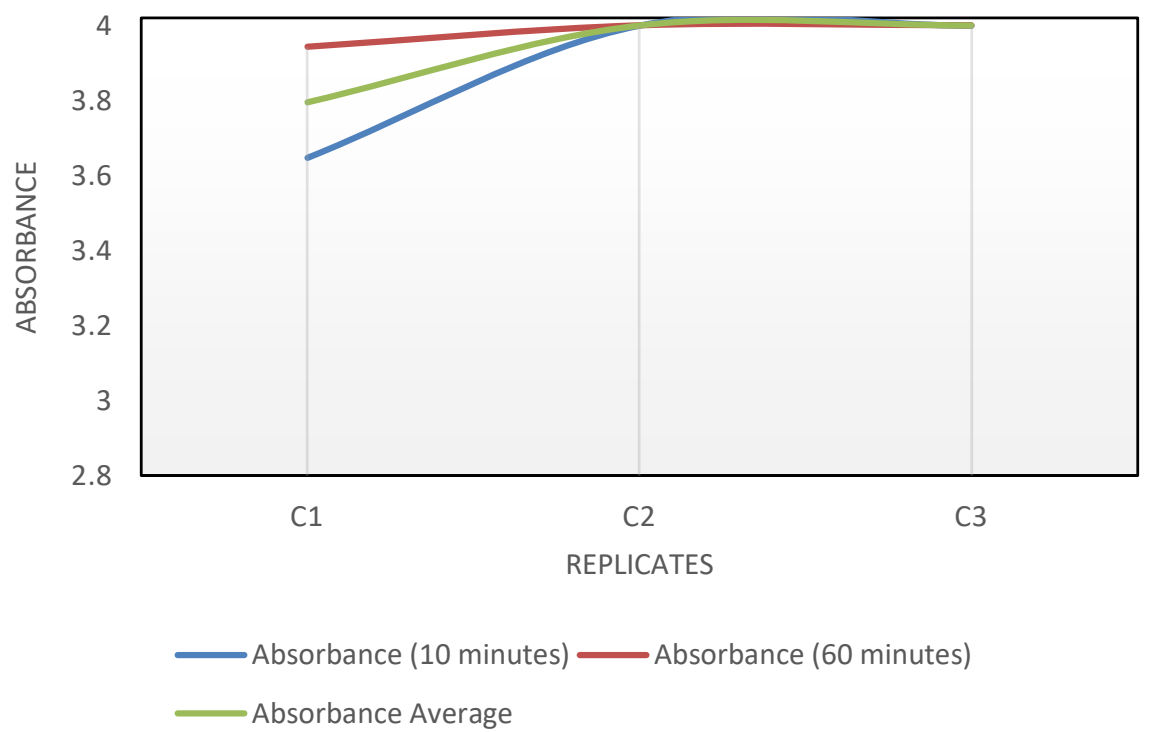

H. Effect of the Concentration of Alagaw Leaf Extract on the Wavelength Peaks of Silver Nanoparticles in 10 minutes interval

a. Difference on the effect of the concentration of Alagaw leaf extract on the wavelength peaks of silver nanoparticles in 10 minutes interval

\begin{tabular}{cccccccc}
\hline \hline & $\begin{array}{c}\text { Sum of } \\
\text { Squares }\end{array}$ & df & $\begin{array}{c}\text { Mean } \\
\text { Square }\end{array}$ & F & Sig. & $\begin{array}{c}\text { Remark } \\
\text { squ }\end{array}$ \\
\hline $\begin{array}{c}\text { Between } \\
\text { Groups }\end{array}$ & 28057.209 & 2 & 14028.604 & 7.918 & $.021^{*}$ & $\mathrm{~s}$ \\
\hline $\begin{array}{c}\text { Within } \\
\text { Groups }\end{array}$ & 10630.133 & 6 & 1771.689 & & \\
\hline Total & 38687.342 & 8 & & & \\
\hline \hline
\end{tabular}

*Level of significance 0.05 
b. Difference on the effect of the concentration of Alagaw leaf extract on the wavelength peaks of silver nanoparticles in 10 minutes interval between the treatments

\begin{tabular}{ccccc}
\hline \hline & & & & \\
(I) Treatment & (J) Treatment & Std. Error & Sig. & Remarks \\
\hline \hline $.20 \mathrm{~g} / \mathrm{mL}$ & $.40 \mathrm{~g} / \mathrm{mL}$ & 34.36751 & .040 & $\mathrm{~S}$ \\
& $.60 \mathrm{~g} / \mathrm{mL}$ & 34.36751 & .026 & $\mathrm{~S}$ \\
\hline \multirow{2}{*}{$.40 \mathrm{~g} / \mathrm{mL}$} & $.20 \mathrm{~g} / \mathrm{mL}$ & 34.36751 & .040 & $\mathrm{~S}$ \\
& $.60 \mathrm{~g} / \mathrm{mL}$ & 34.36751 & .929 & $\mathrm{~ns}$ \\
\hline & $.20 \mathrm{~g} / \mathrm{mL}$ & 34.36751 & .026 & $\mathrm{~S}$ \\
$\star$ & $.40 \mathrm{~g} / \mathrm{mL}$ & 34.36751 & .929 & $\mathrm{~ns}$ \\
\hline \hline The mean difference is significant at the 0.05 level.
\end{tabular}

I. Effect of the Concentration of Alagaw Leaf Extract on the Wavelength Peaks of Silver Nanoparticles in 60 minutes interval

a. Difference on the effect of the concentration of Alagaw leaf extract on the wavelength peaks of silver nanoparticles in 60 minutes interval

\begin{tabular}{cccccccc}
\hline \hline & $\begin{array}{c}\text { Sum of } \\
\text { Squares }\end{array}$ & df & $\begin{array}{c}\text { Mean } \\
\text { Square }\end{array}$ & F & Sig. & Remark \\
\hline \hline $\begin{array}{c}\text { Between } \\
\text { Groups }\end{array}$ & 4009.802 & 2 & 2004.901 & 9.556 & .014 & $\mathrm{~s}$ \\
\hline $\begin{array}{c}\text { Within } \\
\text { Groups }\end{array}$ & 1258.893 & 6 & 209.816 & & \\
\hline Total & 5268.696 & 8 & & & \\
\hline \hline
\end{tabular}

*Level of significance 0.05 
b. Difference on the effect of the concentration of Alagaw leaf extract on the wavelength peaks of silver nanoparticles in 60 minutes interval between the treatments

\begin{tabular}{cccccc}
\hline \hline \multirow{2}{*}{ (I) Treatment } & (J) & Treatment & Std. Error & Sig. & Remarks \\
\hline \multirow{2}{*}{$.20 \mathrm{~g} / \mathrm{mL}$} & $.40 \mathrm{~g} / \mathrm{mL}$ & 11.82696 & .012 & $\mathrm{~S}$ \\
& $.60 \mathrm{~g} / \mathrm{mL}$ & 11.82696 & .073 & $\mathrm{~ns}$ \\
\hline \multirow{2}{*}{$.40 \mathrm{~g} / \mathrm{mL}$} & $.20 \mathrm{~g} / \mathrm{mL}$ & 11.82696 & .012 & $\mathrm{~S}$ \\
& $.60 \mathrm{~g} / \mathrm{mL}$ & 11.82696 & .335 & $\mathrm{~ns}$ \\
\hline \multirow{2}{*}{$60 \mathrm{~g} / \mathrm{mL}$} & $.20 \mathrm{~g} / \mathrm{mL}$ & 11.82696 & .073 & $\mathrm{~ns}$ \\
& $.40 \mathrm{~g} / \mathrm{mL}$ & 11.82696 & .335 & $\mathrm{~ns}$ \\
\hline \hline
\end{tabular}

J. Effect of the Concentration of Alagaw Leaf Extract on the Absorbance Peaks of Silver Nanoparticles in 10 minutes interval

a. Difference on the effect of the concentration of Alagaw leaf extract on the absorbance peaks of silver nanoparticles in $\mathbf{1 0}$ minutes interval

\begin{tabular}{ccccccc}
\hline \hline & $\begin{array}{c}\text { Sum of } \\
\text { Squares }\end{array}$ & Df & $\begin{array}{c}\text { Mean } \\
\text { Square }\end{array}$ & F & Sig. & Remark \\
\hline \hline Between Groups & .341 & 2 & .170 & 1.605 & .276 & ns \\
\hline Within Groups & .637 & 6 & .106 & & \\
\hline Total & .977 & 8 & & & \\
\hline \hline
\end{tabular}

*Level of significance 0.05 
b. Difference on the effect of the concentration of Alagaw leaf extract on the absorbance peaks of silver nanoparticles in 10 minutes interval between the treatments

\begin{tabular}{ccccc}
\hline \hline \multirow{2}{*}{ (I) Treatment } & (J) Treatment & Std. Error & Sig. & Remarks \\
\hline \hline \multirow{2}{*}{$.20 \mathrm{~g} / \mathrm{mL}$} & $.40 \mathrm{~g} / \mathrm{mL}$ & .26599 & .285 & $\mathrm{~ns}$ \\
& $.60 \mathrm{~g} / \mathrm{mL}$ & .26599 & .947 & $\mathrm{~ns}$ \\
\hline \multirow{2}{*}{$.40 \mathrm{~g} / \mathrm{mL}$} & $.20 \mathrm{~g} / \mathrm{mL}$ & .26599 & .285 & $\mathrm{~ns}$ \\
\hline \multirow{2}{*}{$60 \mathrm{~g} / \mathrm{mL}$} & $.60 \mathrm{~g} / \mathrm{mL}$ & .26599 & .412 & $\mathrm{~ns}$ \\
\hline \hline
\end{tabular}

*. The mean difference is significant at the 0.05 level.

K. Effect of the Concentration of Alagaw Leaf Extract on the Absorbance Peaks of Silver Nanoparticles in 10 minutes interval

a. Difference on the effect of the concentration of Alagaw leaf extract on the absorbance peaks of silver nanoparticles in 60 minutes interval

\begin{tabular}{ccccccc}
\hline \hline & $\begin{array}{c}\text { Sum of } \\
\text { Squares }\end{array}$ & df & $\begin{array}{c}\text { Mean } \\
\text { Square }\end{array}$ & F & Sig. & Remarks \\
\hline Between Groups & .021 & 2 & .011 & .806 & .490 & ns \\
Within Groups & .079 & 6 & .013 & & \\
Total & .100 & 8 & & & \\
\hline \hline
\end{tabular}

*Level of significance 0.05 
b. Difference on the effect of the concentration of Alagaw leaf extract on the absorbance peaks of silver nanoparticles in 60 minutes interval between the treatments

\begin{tabular}{ccccc}
\hline \hline & & & & \\
(I) Treatment & $(\mathrm{J})$ Treatment & $\begin{array}{c}\text { Std. } \\
\text { Error }\end{array}$ & Sig. & Remarks \\
\hline \multirow{2}{*}{$.20 \mathrm{~g} / \mathrm{mL}$} & $.40 \mathrm{~g} / \mathrm{mL}$ & .09356 & .509 & $\mathrm{~ns}$ \\
& $.60 \mathrm{~g} / \mathrm{mL}$ & .09356 & .984 & $\mathrm{~ns}$ \\
\hline \multirow{2}{*}{$.40 \mathrm{~g} / \mathrm{mL}$} & $.20 \mathrm{~g} / \mathrm{mL}$ & .09356 & .509 & $\mathrm{~ns}$ \\
& $.60 \mathrm{~g} / \mathrm{mL}$ & .09356 & .601 & $\mathrm{~ns}$ \\
\hline \multirow{2}{*}{$60 \mathrm{~g} / \mathrm{mL}$} & $.20 \mathrm{~g} / \mathrm{mL}$ & .09356 & .984 & $\mathrm{~ns}$ \\
& $.40 \mathrm{~g} / \mathrm{mL}$ & .09356 & .601 & $\mathrm{~ns}$ \\
\hline \hline
\end{tabular}

L. Transmission Electron Microscopy Analysis of Silver Nanoparticles in terms of Size and Shape

a. TEM images of synthesize silver nanoparticles in (a) 60000x magnification. (b) 100000x magnification. (c) 300000x magnification
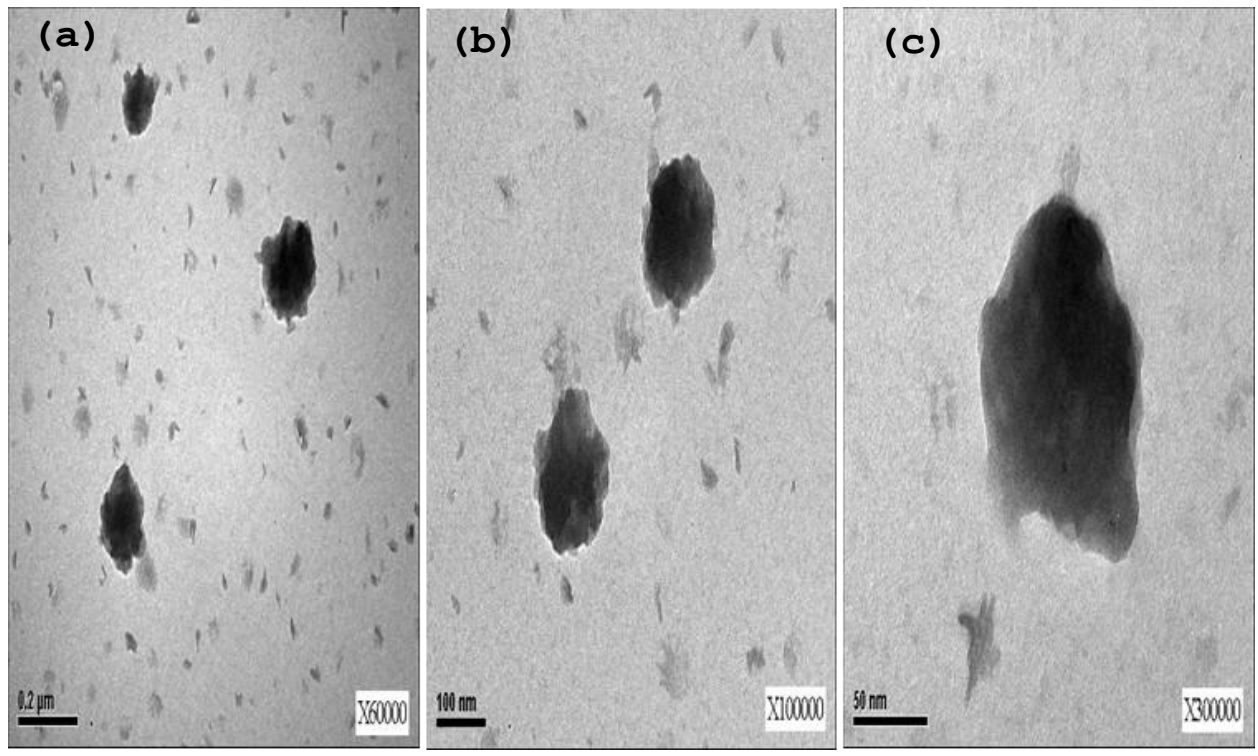
b. Size Distribution of the synthesized silver nanoparticles in 5000x magnification

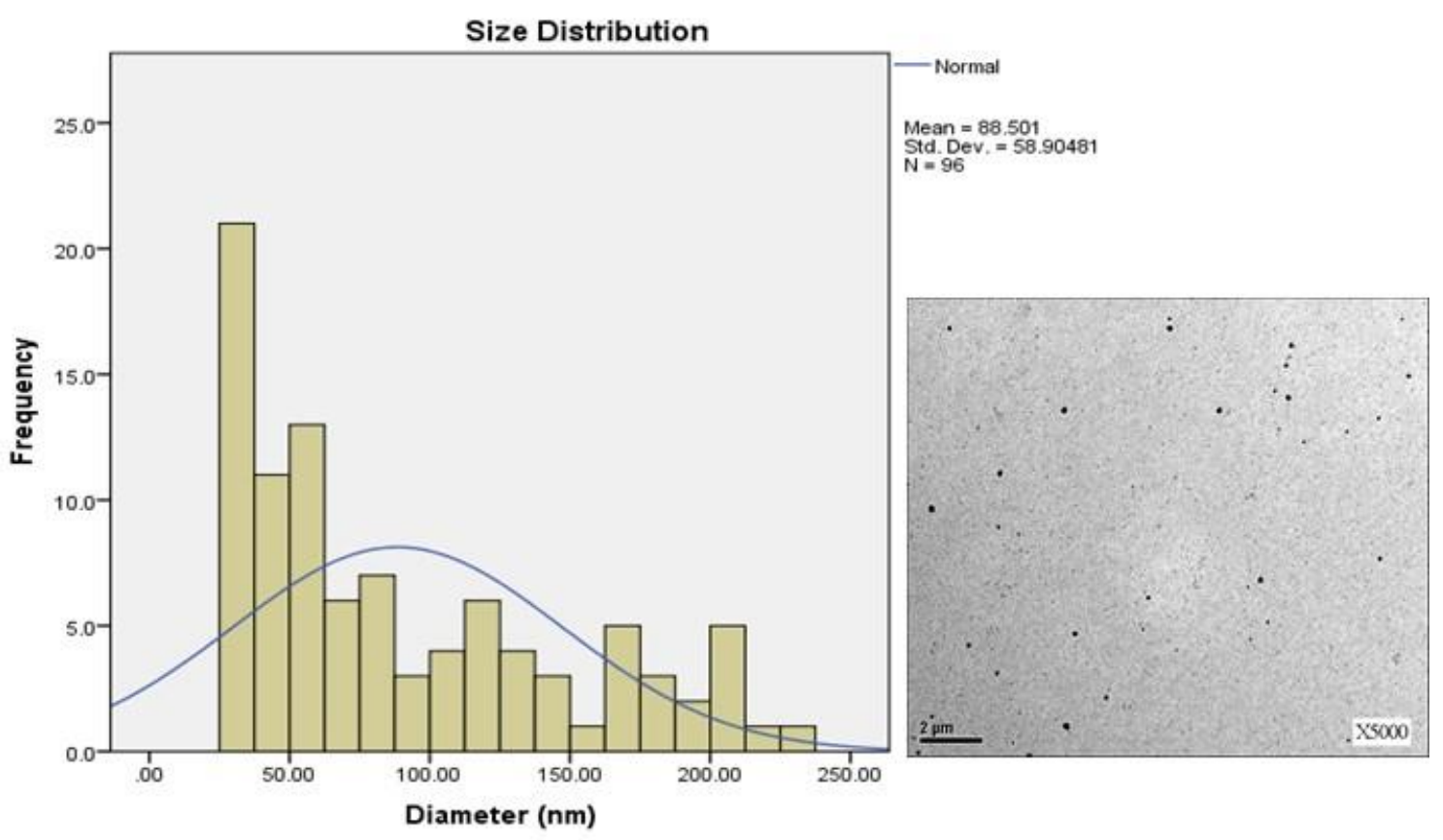

c. Size Distribution of the synthesized silver nanoparticles in $15000 x$ magnification

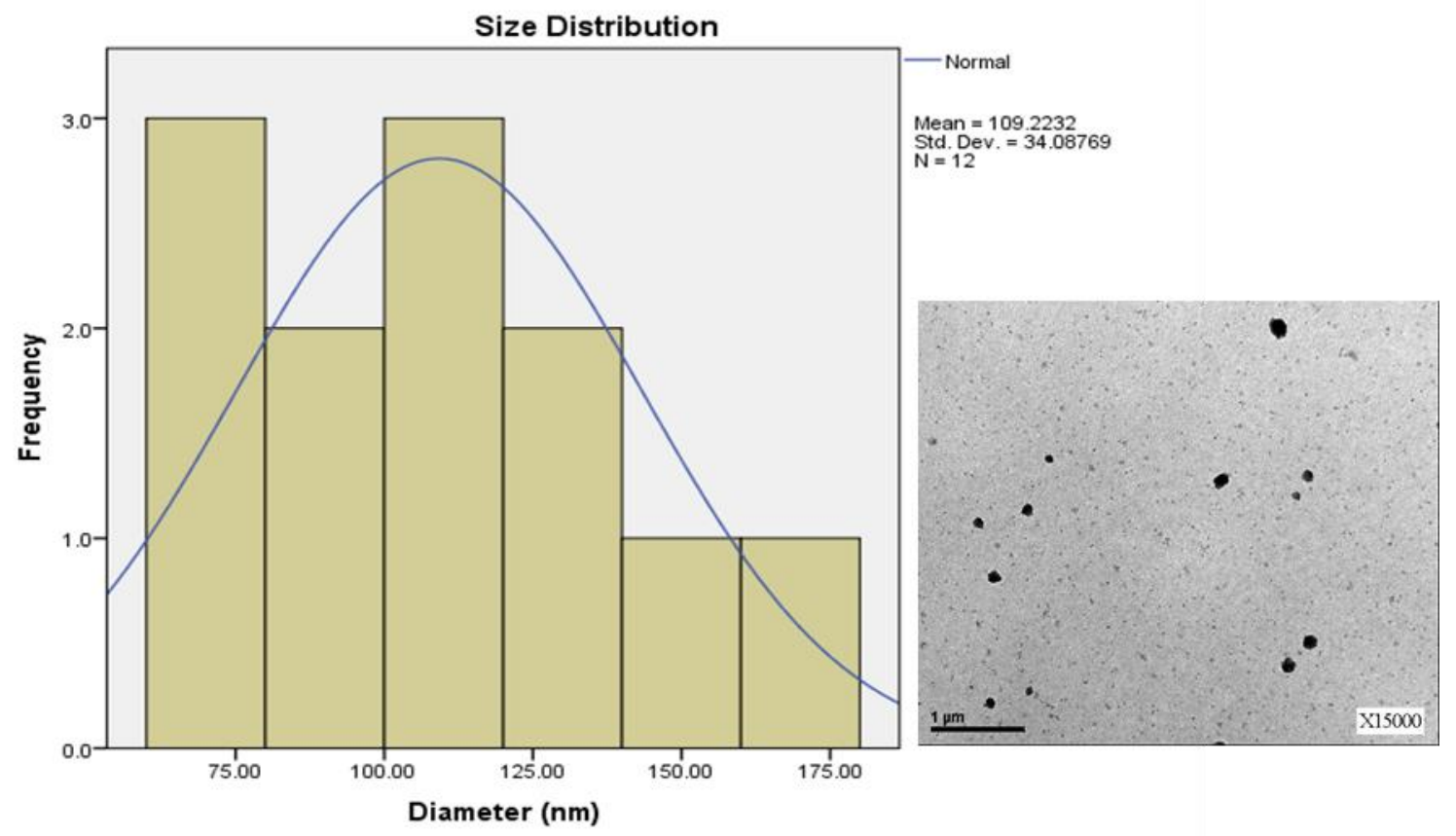

Page 25 of 25 